\title{
Historical perspectives of The American Association for Thoracic Surgery: Mortimer J. Buckley (1932-2007)
}

\author{
Cameron D. Wright, MD, and Cary W. Akins, MD
}

Mortimer John Buckley, the 76th president of The American Association for Thoracic Surgery, was born in Worcester, Massachusetts, on July 1, 1932, to an Irish immigrant family. He attended the College of the Holy Cross and then Boston University Medical School, later being named a distinguished alumnus of both schools. Dr Buckley did all his surgical training at the Massachusetts General Hospital (MGH) and during his general surgical residency spent 2 years in a research fellowship with Dr Andrew Glenn Morrow at the National Institutes of Health. He completed his training in 1966 (Figure 1) and joined the cardiac surgical staff at MGH and the faculty at Harvard Medical School, where he remained for his entire 32-year career.

Dr Buckley, "MJB" to those on the MGH cardiac service and "Mort" to his friends, was a surgical legend with a complex personality. Until his final illness, he was physically imposing and could be both intellectually and physically intimidating yet socially charming. Professionally, Dr Buckley combined raw intelligence, a prodigious memory, great technical facility, tenacity in patient care, an uncompromised work ethic, and absolute dedication to teaching. MJB was unwilling to accept anything less than total commitment to education from his residents and unwavering dedication to the welfare of the patients from his staff. His expectations were high, and while he could make accommodations for lesser degrees of intelligence or innate surgical skills, he accepted nothing less than a resident's absolute best efforts to achieve perfection-no cutting corners or half-hearted attempts. He abhorred wasted talent.

As an educator, Dr Buckley was, in part, a product of his times. As a consequence, he was a demanding and confrontational taskmaster. ${ }^{1} \mathrm{He}$ ran the service like an old school football coach, such as Vince Lombardi, legendary coach of the Green Bay Packers, who said, "Success demands singleness of purpose," or Coach Paul "Bear" Bryant of the University of Alabama, who said, "I make my practices real hard because if a player is a quitter, I want him to quit in practice." As the MGH residents and faculty quickly learned, Mort was an intense competitor, not only in the

From the Department of Thoracic Surgery, Massachusetts General Hospital, Boston, Mass.

Received for publication Feb 18, 2011; accepted for publication April 27, 2011; available ahead of print Aug 8, 2011.

Address for reprints: Cameron D. Wright, MD, Massachusetts General Hospital, Thoracic Surgery, Blake 1570, 55 Fruit St, Boston, MA 02114 (E-mail: wright. cameron@mgh.harvard.edu).

J Thorac Cardiovasc Surg 2013;146:6-8

0022-5223/\$36.00

Copyright (C) 2013 by The American Association for Thoracic Surgery doi:10.1016/j.jtcvs.2011.04.035 hospital but also on the basketball court during "friendly" games at department outings. In all aspects of his life, Dr Buckley played to win.

Every MGH trainee has a favorite "Mort" story to tell, which was typically shared at the 9:30 PM resident on-call meal at the MGH. One vignette illustrates his total knowledge of the cardiac service and need to be in charge:

I [C.D.W.] was just returning to the cardiac service as chief resident after a period on general thoracic. It was very early Saturday morning when I received a request from the on-call medical senior-he needed a temporary intensive care unit bed for a patient who had been resuscitated from a 3 Am cardiac arrest. There were no medical beds, so I gave him a cardiac surgery bed with the proviso that the patient be moved to the cardiac care unit by 9 Am, so that he would not interfere with our work flow. The medical resident agreed, so I did not waken Mort for such a trivial matter. I thought Mort would never know, as he rarely made morning intensive care unit rounds on Saturday, and I had a guarantee that the patient would be gone long before our first case needed a bed. I was delayed getting to the operating room by a ward emergency, so I joined Mort mid case. There was no welcome back to the service. Instead, MJB displayed his classic red neck and a verbal rebuke, followed by a command never to give one of HIS beds away again. Of course, I never gave one of his beds away again.

Although the atmosphere in Dr Buckley's operating room could be very intense, to most of his chief residents he became a mentor-occasionally, to some who did not get the message, he became a tormentor. More than 70 cardiac surgeons were graduates of his training program, many of whom went on to be professors and chiefs of their own training programs. In 1998, at a retirement dinner held in his honor, 69 of his trainees were present as a measure of their loyalty to, and appreciation of, Mort. This second vignette illustrates how the intensity of life on the cardiac service in the 1970s, 1980s, and 1990s was frequently broken up with humor and good times:

When I [C.W.A.] was Dr. Buckley's chief resident in 1975, my father, a general practitioner from a small town in Minnesota and my hero, came to watch me perform an aortic valve replacement with Dr Buckley. The operation seemed to be progressing smoothly and expeditiously, when Dr Buckley chose a quiet moment to turn to my father, who was standing at the 


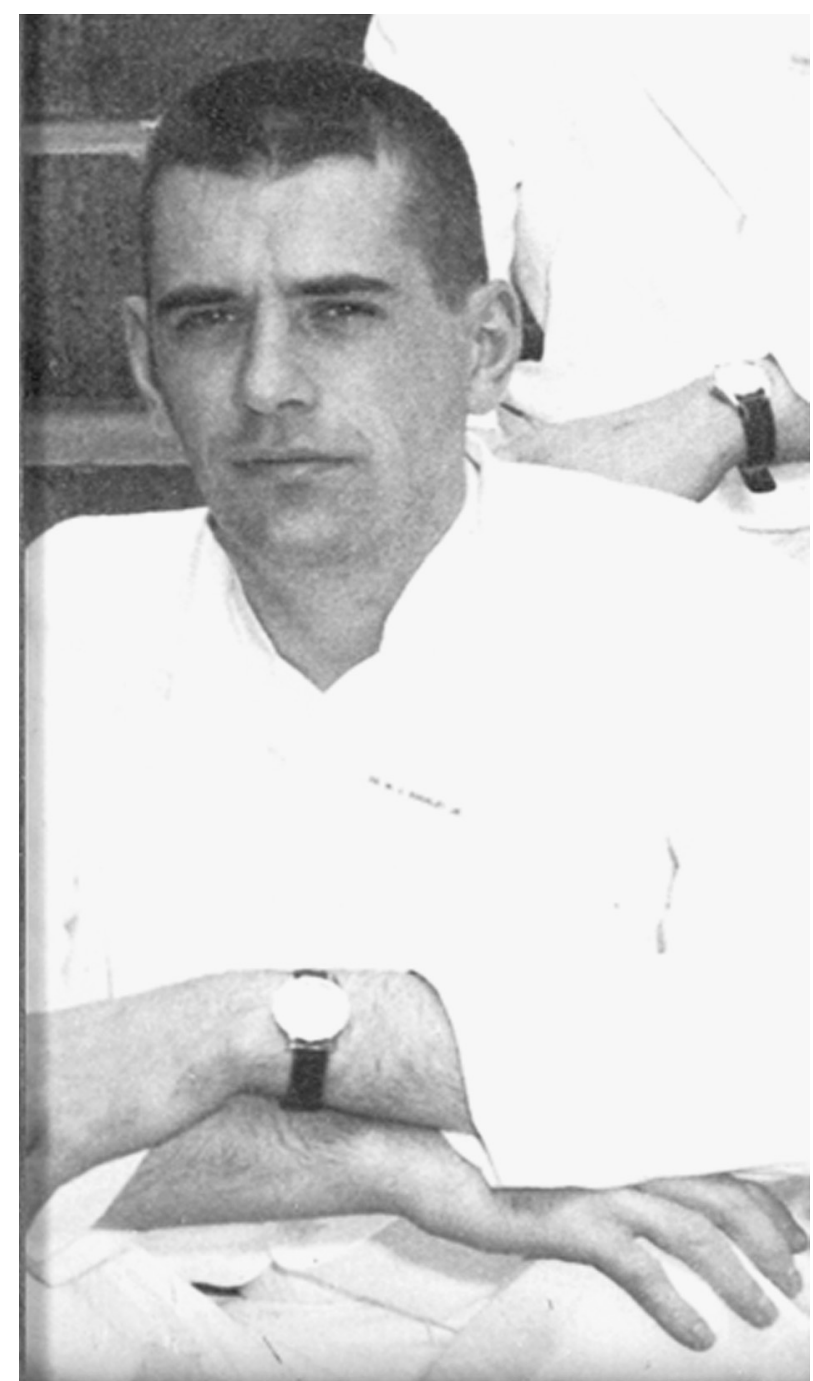

FIGURE 1. Mortimer Buckley at the Massachusetts General Hospital when he was a senior resident.

head of the table, and say, "Dr Akins, I hope that at the conclusion of this operation you will have a few minutes to spend with me in my office. There are some aspects of your son's behavior that we need to discuss." Even behind his mask, you could see my father's jaw drop. Mort waited a few tantalizing seconds and then burst out laughing, and kept laughing until my father smiled...only then did I resume breathing. Mort looked at me and said, "Gotcha!"

As chief of the unit, Dr Buckley was a leader who had a vision and a passion for cardiac surgery at MGH. He would confront cardiology, nursing, anesthesia, the department of surgery, the hospital, the state government -essentially anyone, if he felt that it would benefit the MGH cardiac program. Dr Buckley's defined mission and the team's shared sense of purpose bred camaraderie. His devotion to teaching, not only residents but the entire car-

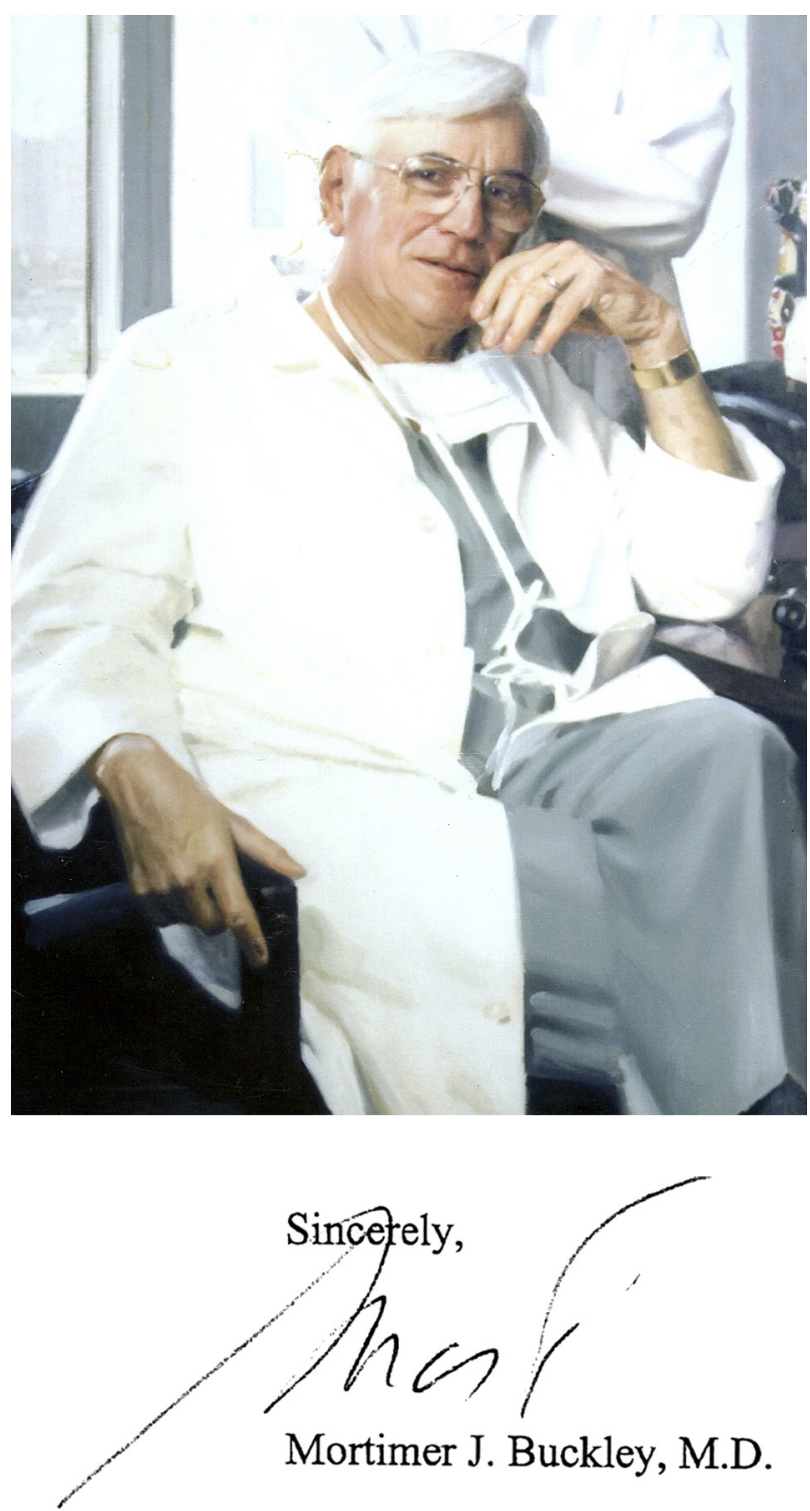

FIGURE 2. Portrait of Mortimer Buckley, which hangs in the conference room that bears his name, and a copy of his signature.

diac surgical team, was recognized by the dedication, in his name, of the intensive care unit conference room in which his official portrait hangs (Figure 2).

As a colleague, Dr Buckley set a high standard of performance and expectation. His work ethic, excellent results, and commitment to teaching set a valuable example for the rest of the staff. As a surgeon, MJB was unflappable in the face of any surgical problem. He was an early innovator in the application of mechanical circulatory support, contributing to the development of the intra-aortic balloon pump and its clinical application to treat acutely ischemic and failing hearts and the mechanical complications of acute myocardial infarction. ${ }^{2}$ Along with associates in cardiac anesthesia, he helped to establish the technique of deep 


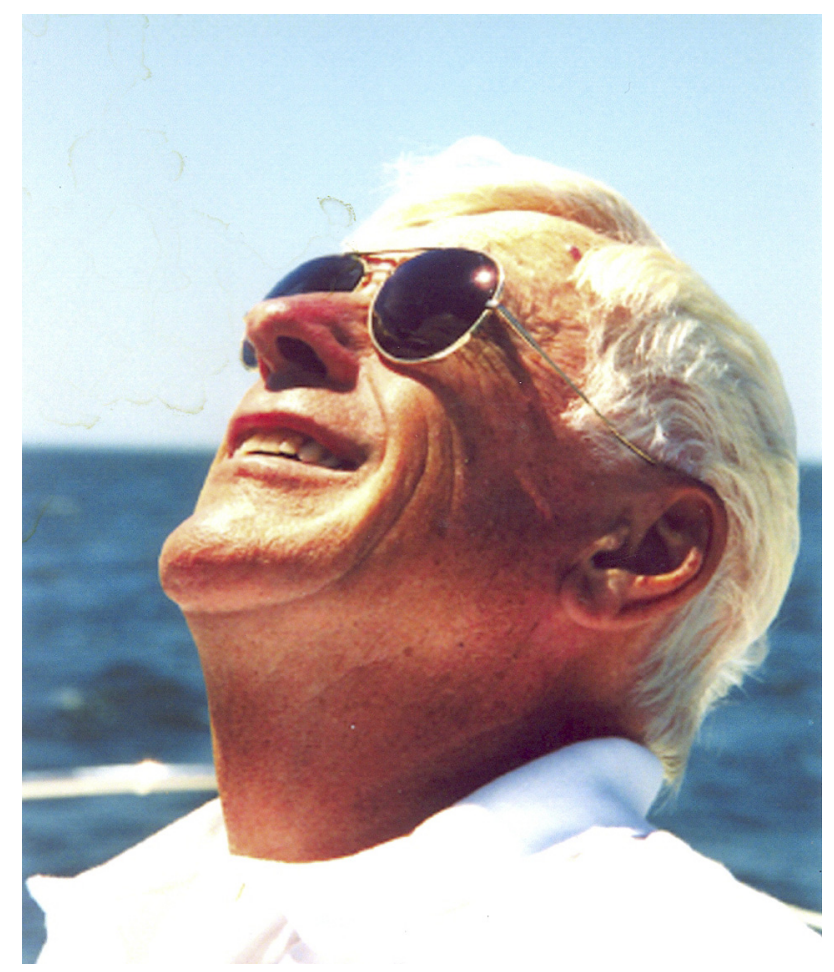

FIGURE 3. Mort sailing and enjoying the day.

hypothermia and hemodilution for the correction of congenital anomalies in infants. His bibliography of more than 200 published articles spans the entire gamut of adult and congenital heart disease. During his later years, unfortunately, he could not motivate himself to write about the lessons learned from 30 years of practice. As a consequence, his wisdom today resides in the minds and hearts of the residents whom he trained and continues to be passed to succeeding generations taught by his pupils.

Dr Buckley was a recipient of the American Heart Association's prestigious Paul Dudley White Award and of the Abraham Colles Medal from the Royal College of Surgeons in Ireland. In April 1996, at The American Association of Thoracic Surgeons meeting in San Diego, Dr Buckley gave his presidential address entitled, "I Would Like to be a Thoracic Surgeon," which dealt with the history and challenges of thoracic surgery training. ${ }^{3} \mathrm{He}$ was prescient in that he called for abolition of the American Board of Thoracic Surgery prerequisite for American Board of Surgery certification and recommended a 6-year training program, including 3 years in general surgery and 3 years in thoracic surgery, similar to the integrated programs being offered today.

Outside of medicine, one could see a different personal side to Mort Buckley, including his ability to be the world's most charming raconteur. He had a well-honed sense of Irish humor and loved to regale those around him with stories. Mort enjoyed playing tennis and golf but was happiest at sea (Figure 3). He was a devoted family man; he adored his wife, Marilyn, and his 4 children, in whom he took great pride. As a host, he was kind, generous, and deferential. A few years after retiring, Mort acquired multiple myeloma-a disease that cut short his well-earned retirement and made his last years difficult and his last few months painful. His courage in the face of those trials provided further inspiration and life lessons to his friends and pupils. Dr Buckley died on November 24, 2007, at the age of 75 in his home in Osterville on Cape Cod.

During the height of Dr Buckley's career, he was often described as "larger than life." Considering the success of his family and the scores of cardiac surgeons he trained who have continued the dissemination of his teachings, we might argue that Dr Mortimer J. Buckley's legacy is even larger than death.

\section{References}

1. Akins CW, Austen WG, Daggett WM, Lytle BW. Mortimer John Buckleymemorial minute. Harvard Gazette. October 10, 2008;1-3.

2. Buckley MJ, Mundth ED, Daggett WM, Gold HK, Leinbach RC, Austen WG. Surgical management of ventricular septal defect and mitral regurgitation complicating acute myocardial infarction. Ann Thorac Surg. 1973;16:598-609.

3. Buckley MJ. I would like to be a thoracic surgeon. J Thorac Cardiovasc Surg. 1996;112:1135-42. 